\title{
Influence of breeds genetic composition on the quality of milk from primiparous cows
}

\author{
Melo, A. F. ${ }^{1}$, Silva, M. A. P. ${ }^{1}$, Silva, F. R. ${ }^{1}$, Carmo, R. M. ${ }^{1}$, Neves, R. B. S. ${ }^{2}$, Nicolau, E. S. ${ }^{2}$ and \\ Lage, M. E. ${ }^{2}$ \\ ${ }^{1}$ Unidade de Zootecnia, Instituto Federal Goiano - Câmpus Rio Verde, Rodovia Sul Goiana, Km 01, Caixa Postal 66, \\ CEP 75901-970, Rio Verde, Goiás, Brazil. \\ ${ }^{2}$ Laboratório de Qualidade do Leite do Centro de Pesquisa em Alimentos da Escola de Veterinária e Zootecnia da \\ Universidade Federal de Goiás, Campus II da UFG, Rodovia GO-080 (saída para Nova Veneza), CEP 74001-970, \\ Goiânia, Goiás, Brazil.
}

Received 26 August, 2014; Accepted 25 March, 2015

\begin{abstract}
Forty-four crossbred primiparous cows participated in this study, namely: $151 / 2$ animals corresponding to $1 / 2$ Holstein (HO) x 1/2 Gyr; $153 / 4$ animals corresponding to (3/4 HO x 1/4 Gyr) and $147 / 8$ animals corresponding to $(7 / 8 \mathrm{HO} \times 1 / 8 \mathrm{Gyr})$ raised under similar handling and feeding conditions. The sample collection was carried out between January and March 2013. To compare the quality of milk among breeds genetic compositions, the study was set up in a completely randomized design. Data of variables fat, protein, lactose contents, fat free dry matter (DDE), urea, somatic cell count, electrical conductivity, $\mathrm{pH}$, titratable acidity and production were submitted to analysis of variance using the Tukey test at $5 \%$ probability for comparison of means between treatment 1 (1/2 HO x 1/2 Gyr), treatment 2 (3/4 HO x 1/4 Gyr) and treatment $3(7 / 8 \mathrm{HO} \times 1 / 8 \mathrm{Gyr})$. Statistical analyses were performed using the SISVAR ${ }^{\circledR}$ - UFLA software. Correlation analysis between variables was performed using the ASSISTAT software. The results demonstrate that the genetic makeup of the different races holstein / Gyr primiparous cows did not affect the quality of the milk produced. The values of the chemical constituents of milk have been considered suitable for human consumption. Titratable acidity and milk production were higher for $3 / 4$ Holstein/Gyr animals.
\end{abstract}

Key words: Protein, electrical conductivity, titratable acidity, Holstein, Gyr.

\section{INTRODUCTION}

In Brazil, the Holstein breed is the most exploited due to higher milk production compared with other breeds, especially in more intensive systems. According to Huang et al. (2009), the limiting factor for the use of Holstein cows is that the higher the milk production, the lower the reproductive potential. High reproductive efficiency is an important factor to ensure profitable milk production.

Another aspect that has generated concern, particularly

${ }^{*}$ Corresponding author. E-mail: marcotonyrv@yahoo.com.br.

Author(s) agree that this article remains permanently open access under the terms of the Creative Commons Attribution License 4.0 International License 
in Holstein herds of high productivity is the reduced productive efficiency in dairy herds caused by climatic factors (Almeida, 2007).

Gyr animals are adapted to tropical conditions and show lower incidence of diseases than breeds in temperate climates (Van Melis et al., 2007). The Gyr is one of the principal Zebu breeds, these breeds play an important role in the Brazilian dairy farming (Silva, 2012).

The Gyr breed stands out in relation to other breeds of Indian origin for the excellent productive and reproductive performances, which are associated with rusticity, good milk production performance, for manual as well as mechanical milking. A viable alternative is the crossing between breeds of Indian (Zebu) and breeds of European origin (Taureans), which combines the tropical climate, Indian breeds with the productive potential of taurine breeds (Vasconcellos et al., 2003). The crossing between Holstein and Gyr animals is the origin of the Girolando breed, a rustic animal adapted to the tropical climate and adequately efficient in milk production.

One of the frequent concerns in dairy farming is the order of deliveries of dairy cows. Soares et al. (2009) reported that the average milk production of adult cows (above 4 births) is higher than first- and second-order cows, which improves the economic value of the herd.

The high production of Holstein milk and the highest concentration of solids in the milk of animals of Zebu, is a factor to be considered for choosing the cross, that is, the Dutch Animal produce more milk with lower solids content, as the zebu cows produce less milk with higher solids content. Thus, the cross becomes indispensable, because we can gather the two characteristics in the same animal.

The production efficiency of cows with different breeds genetic compositions (Holstein/Gyr) is still unknown. There is a need to seek optimization of the productivity and quality of milk from cows that originated from the crossing of cows of European and Indian origins, justifying the conduction of studies in this area. Therefore, the aim of this study was to evaluate the physicochemical composition, production and somatic cell count (SCC) of milk from primiparous cows with different breeds genetic compositions (Holstein/Gyr).

\section{MATERIALS AND METHODS}

The study was conducted during the rainy season, between January and March 2013, on a cattle farm located in Rio Verde Goiás, Brazil (17 56 '3:38 "S and $5{ }^{\circ} 2^{\prime}$ ' 3.85" W). The average temperature during the experimental period was $32^{\circ} \mathrm{C}$ and relative humidity of $37 \%$. The region has climate with two distinct seasons: the dry season (May to October) and rainy (November to April).

The herd consisted of 140 crossbred lactating cows, producing approximately 19.22 liters/cow/day. The animals used in the experiment had average age of 36 months, weighing between 350 $\mathrm{kg}$ and $490 \mathrm{~kg}$ in stage of lactation between 90 and 110 days.

The study included 15 animals mestizo $1 / 2$ blood, that is F1 $(50 \%$ of Holstein $x$ Gyr $50 \%), 15$ animal crossbred 3/4, that is, F2 (75\% of Holstein $x$ Gyr 25\%) and 14 crossbred animals $7 / 8$, or F3 (87.5\%
Table 1. Chemical composition of Brachiaria brizantha cv Marandu pasture offered to lactating cows.

\begin{tabular}{lcc}
\hline Composition & $(\%)$ & SD \\
\hline Dry matter & 28.33 & 1.72 \\
Mineral matter & 7.99 & 0.14 \\
Crude protein & 16.01 & 0.36 \\
Neutral detergent fiber & 55.75 & 2.68 \\
Acidd etergent fiber & 33.68 & 1.94 \\
Ether extract & 2.80 & 0.36 \\
Total digestible nutrients & 67.39 & 1.82 \\
\hline
\end{tabular}

Table 2. Chemical composition of the concentrate offered to primiparous lactating Holstein/Gyr cows.

\begin{tabular}{lcc}
\hline Composition & (\%) & SD \\
\hline Dry matter & 89.08 & 1.78 \\
Mineral matter & 6.39 & 0.45 \\
Crude protein & 22.12 & 0.22 \\
Neutral detergente fiber & 26.32 & 0.60 \\
Acid detergent fiber & 18.26 & 0.83 \\
Ether extract & 4.51 & 0.25 \\
Total digestible nutrients & 87.40 & 1.04 \\
\hline
\end{tabular}

of Holstein $x$ Gyr $12.5 \%$ ), raised in similar handling and feeding conditions. The cows received all mandatory vaccinations (foot-andmouth disease, brucellosis and anthrax) in accordance with recommendations of the veterinary and according to requirements of the vaccine schedule set by the Board of Agriculture and Livestock Defense of the State of Goiás.

For the development of this study, the dairy cows grazed on intensively managed Brachiaria brizantha cv Marandu pasture, whose chemical composition is shown in Table 1.

Cows had free access to the resting area with natural and artificial shade, water and mineral salt ad libitum. The assessment of the nutritional value of forage was performed after collection of samples, using a metal square with an area of $1 \mathrm{~m}^{2}$. The square area was released at random in the area for measurement of pasture height with the aid of a ruler. The forage samples were collected once a week throughout the experimental period (January-March 2013). Shortly after, the material was collected with the aid of pruning shears, and then the samples were placed in properly labeled plastic bags for later analysis. Commercial protein concentrate was daily provided to cows in lactation at a ratio of $1 \mathrm{~kg}$ of concentrate per $4 \mathrm{~L}$ of milk produced (Table 2 ).

The assessment of the nutritional components of commercial protein concentrate was performed after collection of samples directly obtained from the storage bags. The concentrated samples were collected once a week during the entire experimental period (January-March 2013). The collected material was placed on properly labeled plastic bags. Then, a representative sample was collected for chemical composition assessment.

Dry matter (DM) of fodder and concentrate were determined in an oven with forced air circulation at $55^{\circ} \mathrm{C}$. Subsequently, the samples were ground in a $1 \mathrm{~mm}$ sieve for analysis.

$D M$, crude protein (CP), neutral detergent fiber (NDF), acid detergent fiber (ADF), ether extract (EE) and mineral matter (MM) 
Table 3. Mean values and standard deviation of fat (\%), protein (\%), lactose (\%), fat free dry matter defatted dry extract (\%), urea $(\mathrm{mg} / \mathrm{dL})$, somatic cells count $(x 1000 \mathrm{SCC} / \mathrm{mL})$, electrical conductivity $\left(\mathrm{mS} / \mathrm{cm}^{2}\right), \mathrm{pH}$ and titratable acidity $(\mathrm{g}$ of lactic acid/100 $\mathrm{mL})$ of milk from Holstein/Gyr cows.

\begin{tabular}{|c|c|c|c|c|c|}
\hline \multirow{2}{*}{ Parameter } & \multicolumn{3}{|c|}{ Breeds genetic composition Holstein/Gyr } & \multirow{2}{*}{ VC CV (\%) } & \multirow{2}{*}{$p$-value } \\
\hline & $1 / 2(n=75)$ & $3 / 4(n=75)$ & $7 / 8(n=70)$ & & \\
\hline Fat & $3.33 \pm 0.59$ & $3.27 \pm 0.60$ & $3.39 \pm 0.68$ & 18.73 & 0.4895 \\
\hline Protein & $3.16 \pm 0.35$ & $3.07 \pm 0.27$ & $3.12 \pm 0.35$ & 10.51 & 0.2186 \\
\hline Lactose & $4.57 \pm 0.31$ & $4.59 \pm 0.22$ & $4.58 \pm 0.20$ & 5.44 & 0.8704 \\
\hline DDE FFDM & $8.76 \pm 0.42$ & $8.66 \pm 0.40$ & $8.70 \pm 0.34$ & 4.44 & 0.3140 \\
\hline Urea & $17.77 \pm 3.16$ & $18.13 \pm 5.19$ & $18.73 \pm 4.93$ & 24.77 & 0.4333 \\
\hline SCC & $382 \pm 538$ & $293 \pm 455$ & $460 \pm 655$ & 147.02 & 0.1959 \\
\hline EC & $4.89 \pm 0.49$ & $4.81 \pm 0.35$ & $4.80 \pm 0.31$ & 8.09 & 0.3274 \\
\hline $\mathrm{pH}$ & $6.35 \pm 0.45$ & $6.30 \pm 0.53$ & $6.30 \pm 0.50$ & 7.82 & 0.7804 \\
\hline TA & $0.163 \pm 0.018 \mathrm{ab}$ & $0.167 \pm 0.020 \mathrm{a}$ & $0.159 \pm 0.019 b$ & 11.20 & 0.0290 \\
\hline
\end{tabular}

Means followed by different letters in the row differ significantly $(p<0.05)$ in accordance with $5 \%$ Tukey test. $n=$ number of samples collected. VC CV = variation coefficient. DDE = defatted dry extract; FFDM = fat free dry matter; SCC = somatic cells count; EC = electrical conductivity; TA = titratable acidity.

of fodder and concentrate were determined as described by Silva and Queiroz (2002).

Total digestible nutrients (TDN) were determined using the following mathematical equation: $\operatorname{TDN}(\%)=105.3-(0.68 \times \%$ NDF), according to NRC (1996).

Cows were milked twice a day; the first milking was performed at 6:00 am and the second at 4:00 pm. The production of animal milk used in the study were measured only at baseline.

Milk samples of lactating cows were collected once a week for a period of three months (January-March 2013), at the first milking of the day. Milk samples were always collected from the same animals throughout the experimental period.

At the time of milking, the first three jets of milk were collected in a mug of black bottom for detection of clinical mastitis, positive animals were not milked.

Milk of each cow was collected in individual milk meters provided with a valve. Before collection, the milk was stirred for $5 \mathrm{~s}$. Then, the milk sample was taken by positioning the valve in the emptying option, transferring the content to the milk collector.

Sterilized bottles with capacity of $40 \mathrm{ml}$ containing Bronopol ${ }^{\circledR}$ were used for analysis of chemical composition and somatic cell count (SCC). All bottles were previously identified with labels containing barcodes corresponding to the code of each animal. Milk volume (L), of each animal was measured at the beginning of the experimental period.

After collection, milk samples were stored in isothermal boxes containing ice and sent for analyses to the Laboratory of Milk Quality - Food Research Centre, School of Veterinary and Animal Science, Federal University of Goiás.

The fat, protein, lactose and defatted dry extract (DDE) fat free dry matter content were determined using the MilkoScan 4000 equipment (Foss Electric A/S. Hillerod Denmark). According to IDF (2000); the results were expressed as mass percentage (\%); urea contents were determined by differential Fourier transform infrared spectroscopy (FTIR) using Lactoscope equipment (Delta Instruments). The results were expressed as $\mathrm{mg} / \mathrm{dL}$. Somatic cell counts (SCC) were determined by flow cytometry according to IDF (2006); results were expressed as $\mathrm{SC} / \mathrm{mL}$. The electrical conductivity of milk was determined using a conductivity meter TECNOPON ${ }^{\circledR}$ model mCA - 150, with results expressed as $\mathrm{mS} / \mathrm{cm}^{2}$. $\mathrm{pH}$ was measured using bench microprocessor W3B pH meter from Bel Engineering ${ }^{\circledR}$. Acidity was determined by titration according to the method of AOAC (1995) and the results were expressed as grams of lactic acid per $100 \mathrm{~mL}$ of milk.

The study was set up in a completely randomized design (CRD). For comparison of the milk quality between breeds genetic compositions of cows, data of variables fat, protein, lactose contents, fat free dry matter DDE, urea, SCC, electrical conductivity, $\mathrm{pH}$, titratable acidity and production were analyzed by ANOVA using the Tukey test at $5 \%$ probability. For comparison of means between treatments, statistical analyses were performed using the SISVAR ${ }^{\circledR}$ - UFLA software. Correlation pearson analysis between variables (breeds, production, fat, protein, lactose contents, fat free dry matter, urea, SCC, electrical conductivity, $\mathrm{pH}$, titratable acidity) was performed using the ASSISTAT software (Silva and Azevedo, 2009).

\section{RESULTS AND DISCUSSION}

The average results and standard deviations of the physicochemical composition and SCC of milk from primiparous Holstein /Gyr crossbred cows are shown in Table 3.

According to the values in Table 3 , no significant differences $(p>0.05)$ in milk fat content between breeds genetic groups were observed. The variation coefficient (VCCV) was $18.73 \%$. The fat content of samples ranged from 3.27 to $3.39 \%$ (Table 3 ). The results were above the limit established by Brazilian legislation, which recommends a minimum fat value of $3.0 \%$ (Brasil, 2011). These results were lower than those observed by Lima et al. (2006), who found fat contents from 3.34 to $3.56 \%$ for Ctype pasteurized milk produced in the semiarid region of the state of Pernambuco.

Better results than those obtained in this study were reported. Higher results than those obtained in this study have been reported by Mendes et al. (2010), who determined fat contents up to $3.8 \%$ when evaluating the quality of cow's milk sold in the city of Mossoró, RN, Brazil.

Varying amounts of nutrients daily ingested by lactating 
cows can cause oscillations in the major milk components such as fat, protein and lactose. We can observe that milk fat values were close to the protein, explaining that animals consume a larger amount of concentrate, or roughage to concentrate in the diet is low, increasing milk protein content and decreasing the fat content.

There was no significant difference $(p>0.05)$ in the protein content of milk between breeds genetic groups, and the variation coefficient (VC)CV was $10.51 \%$. The average protein values of milk from primiparous Holstein $x$ Gyr cows ranged from 3.07 to $3.16 \%$. These results were higher than those proposed by Normative Instruction 62/2011, which calls for minimum levels of crude protein $2.9 \%$. Values similar to those obtained in this study were observed by Mota et al. (2008), who assessed production performance and milk composition of Holstein cows in late phase of lactation and found protein contents ranging from 2.97 to $3.16 \%$.

An important factor that influences the protein content in milk is the phase of lactation of cows. Lactating cows aged over seven years tend to produce milk with higher protein content and compared to first-parity cows (Noro et al., 2006).

To investigate production and quality of milk from Holstein cows according to the parity order, Souza et al. (2010) found no significant effect of the number of lactation on protein content, with mean value of $3.23 \%$.

The lactose results did not differ significantly, with average values of $4.57,4.59$ and $4.58 \%$, for primiparous Holstein/Gyr, 1/2, 3/4 and $7 / 8$ cows respectively. Regardless of breed genetic composition, lactose was synthesized by the mammary gland of cows in similar amounts.

Lactose results similar to those obtained in the present study (4.42\%), were found by Botaro et al. (2011) in a study aimed at evaluating the composition and protein fraction of milk from commercial herds in the state of São Paulo, while Fukumoto et al. (2010) reported an average of $4.2 \%$ lactose when assessing milk production and composition, dry matter intake and stocking rate in tropical grass pasture managed under rotational grazing system.

The fat free dry matter content defatted dry extract (DDE) did not differ significantly ( $p>0.05$ ) between breeds genetic groups, and the VC CV was $4.44 \%$. The values were $8.76 \%$ for milk from $1 / 2$ primiparous cows; $8.66 \%$ for milk from $3 / 4$ cows and $8.70 \%$ for milk from $7 / 8$ cows. These results were consistent with the IN 62/2011 values, which establishes minimum fat free dry matter DDE value of $8.4 \%$ in milk.

DDE fat free dry matter contents values similar to those obtained in this study have been reported by Cerdótes et al. (2004), which ranged between 8.55 and $8.75 \%$ when investigating the production and composition of milk from cows of four breeds genetic groups submitted to two feeding managements.
The urea concentrations in milk produced by breeds genetic groups 1/2, $3 / 4$ and $7 / 8$ were $17.77,18.13$ and $18.73 \mathrm{mg} / \mathrm{dL}$, respectively, and no significant difference $(p>0.05)$ in the urea levels among these groups was observed. The CV variation coefficient (VC) was $24.77 \%$.

According to Wang et al. (2007), increased urea levels in milk are influenced by metabolizable protein present the diet offered to lactating cows. Fluctuations in the crude protein levels in the diet and the way it is provided to lactating cows considerably alter the concentrations of ruminal ammonia and consequently the level of nitrogen in the form of urea in blood and also in milk (Hojman et al., 2005).

Urea levels below $12 \mathrm{mg} / \mathrm{dL}$ and above $18 \mathrm{mg} / \mathrm{dL}$ may result from improper nutrition management. Based on the chemical analyses of concentrate and fodder, (Tables 1 and 2), concentrate and fodder were excellent protein sources for lactating cows.

Aquino et al. (2007) observed urea concentrations in milk ranging from 16.59 to $17.97 \mathrm{mg} / \mathrm{dL}$ when studying the effect of increasing urea levels in the diet of dairy cows on milk production and physicochemical composition.

The average SCC did not differ significantly $(p>0.05)$. The variation coefficient CV was $147.02 \%$, with values of $382,000,293.000$ and $460.000 \mathrm{SC} / \mathrm{mL}$, obtained from primiparous Holstein/Gyr, 1/2, $3 / 4$ and $7 / 8$ cows, respectively. These values are below limits established by Brazilian legislation. The high variation coefficient of the SCC was due to the large amplitude of counts, whose standard deviations were 538.000, 455,000 and 655,000 $\mathrm{SC} / \mathrm{mL}$ for the three breeds genetic compositions studied.

The SCC of milk should not exceed the limit of 600,000 $\mathrm{SC} / \mathrm{mL}$ of milk, as described in the Normative Instruction IN 62 (Brasil, 2011) for the period from January 1, 2012 to June 30,2014 , in the region under study, which is the southwestern state of Goiás, located in the Mid-western region of Brazil.

The gradual increase in somatic cells count causes a decline in production and influences the physicochemical characteristics of milk, in enzymatic activity, coagulation time, yield and quality of dairy products (Arashiro et al., 2006).

Cunha et al. (2008) evaluated the relationship between subclinical mastitis and SCC with number of lactations, production and chemical composition of milk from Holstein cows and observed that animals with larger number of lactations had higher SCC values and cows that had SCC above $100,000 \mathrm{SC} / \mathrm{mL}$ had lower milk production.

Besides SCC, there are other features also related to the occurrence of mastitis, among those changes in the concentration of anions and cations in milk, which is determined by the electrical conductivity and deserves attention for being a relatively easy and inexpensive method for the diagnosis of subclinical mastitis (Zafalon et al., 2005). 
Table 4. Milk production variation of primiparous Holstein/Gyr cows.

\begin{tabular}{|c|c|c|c|c|c|}
\hline \multirow{2}{*}{ Parameter } & \multicolumn{3}{|c|}{ Breeds genetic composition Holstein/Gyr } & \multirow{2}{*}{ VC CV (\%) } & \multirow{2}{*}{ P-value } \\
\hline & $1 / 2(n=75)$ & $3 / 4(n=75)$ & $7 / 8(n=70)$ & & \\
\hline Milk production (L) & $18.41 \pm 3.24 b$ & $20.25 \pm 2.92 a$ & $19.01 \pm 3.32 b$ & 16.44 & 0.0016 \\
\hline Mean production $(\mathrm{L})$ & \multicolumn{5}{|c|}{19.22} \\
\hline
\end{tabular}

Means followed by different letters in row are statistically different $(p<0.05)$ by the Tukey test. $n=$ number of samples collected. VC CV $=$ variation coefficient.

Electrical conductivity measures the ability of a solution to conduct electrical current between two electrodes and is given in milliSiemens per centimeter $(\mathrm{mS} / \mathrm{cm})$.

As described in Table 3, no significant difference ( $p>0.05)$ for the average electrical conductivity values between the breeds genetic groups was observed, with values of $4.89,4.81$ and $4.80 \mathrm{mS} / \mathrm{cm}$, obtained from primiparous Holstein/Gyr, 1/2, 3/4 and 7/8 cows, respectively. The CV was $8.09 \%$.

The electrical conductivity of milk ranges from 4.61 $\mathrm{mS} / \mathrm{cm}$ to $4.92 \mathrm{mS} / \mathrm{cm}$ (Ferreira, 2007), therefore, the means of this study are within the allowable limit for EC. According to Santos (2005), the EC values of milk increase to $5.37 \mathrm{mS} / \mathrm{cm}$ in subclinical cases and to 6.73 $\mathrm{mS} / \mathrm{cm}$ for clinical cases of mastitis.

In a study by Della Libera et al. (2011) evaluating methods for detection of mastitis, the results indicated that when used for this purpose, the EC must be used with caution, because this parameter may be influenced by age, stage of lactation, production, season of year, milk fraction collected and pathogenic agents.

According to Zafalon et al. (2005), major changes in the physicochemical characteristics of milk occur in cows with mastitis, especially regarding electrical conductivity and $\mathrm{pH}$.

$\mathrm{pH}$ has great importance in milk technology because all fermentative phenomena, processes of butter formation, protein precipitation and pasteurization results depend on milk pH (Ferreira, 2007).

According to the results in Table 3 , average $\mathrm{pH}$ values of $6.35,6.30$ and 6.30 , corresponding to primiparous Holstein/Gyr, 1/2, 3/4 and 7/8 cows, respectively, did not differ ( $p>0.05)$. The high SCC milk, demonstrating that animals showed subclinical mastitis regardless of the race, that is, these microorganisms present in the milk directly influenced $\mathrm{pH}$ drop.

Average values for itratable acidity were significantly different $(p<0.05)$ between breeds genetic groups, $3 / 4$ Holstein/Gyr cows produced milk with higher acidity $(0.167 \mathrm{~g}$ of lactic acid/100 mL) compared to $1 / 2$ and $7 / 8$ cows $(0.163$ and $0.159 \mathrm{~g}$ of lactic acid/100 mL, respectively).

According to Normative Instruction $N^{0} 62$ (Brasil, 2011), bovine milk is considered of good quality when showing acidity values between 0.14 and $0.18 \mathrm{~g}$ of lactic acid/100 $\mathrm{mL}$ of milk, which can be evidenced in this study because all breeds genetic groups evaluated showed normal values.

According to Santos and Fonseca (2006), soon after milking, milk has a slightly acid reaction due to some of the components. This acidity, called natural or apparent, is caused by albumin $\left(1^{\text {st }} \mathrm{D}\right)$, citrate $\left(1^{\mathrm{st}} \mathrm{D}\right)$, carbon dioxide $\left(1^{\text {st }} D\right)$, caseins $\left(5^{\text {th }} D\right.$ and $\left.6^{\text {th }} D\right)$ and phosphate $\left(5^{\text {th }} \mathrm{D}\right)$.

The results of physicochemical parameters of milk from primiparous Holstein/Gyr, 1/2, 3/4 and 7/8 cows, indicated good quality and compliance with standards established by law.

The mean estimates of daily milk production of different breeds genetic groups areshown in Table 4, expressed as liters of milk/day.

Among the genotypes evaluated, 3/4 Holstein/Gyr animals were more productive than in $7 / 8$ and $1 / 2$ animals, and this result can be partly explained due to the condition of primiparous cows, which are still under development, being one of the variables that affect production (Coffey et al., 2006).

Lower results were described by Vilela et al. (2007) evaluating Holstein cows in lactation up to 200 days grazing on coast-cross grass and supplemented with $3 \mathrm{~kg}$ or $6 \mathrm{~kg}$ concentrate/cow/day, with production of $15.5 \mathrm{~kg}$ and $19.1 \mathrm{~kg}$ of milk/cow/day. Milk production values higher than those obtained in this study were reported by Silva et al. (2011) evaluating the production of milk from multiparous Holstein cows of small, medium and large size, with values from 30.56 to $31.07 \mathrm{~kg} / \mathrm{milk} /$ day and average of $23.27 \mathrm{~kg}$.

Glória et al. (2006) evaluated the effects of breeds genetic composition and environmental factors on milk production of Holstein-Gyr crossbred cows and observed that the breeds genetic composition directly reflects the increase in total milk production with increased contribution from Holstein breed.

The linear correlation results between breeds, milk volume produced, SCC, electrical conductivity, $\mathrm{pH}$, titratable acidity and chemical components of milk are presented in Table 5.

There was no significant linear correlation $(p>0.05)$ between breeds genetic composition and milk production, content, protein, lactose, fat free dry matter DDE, SCC, urea, $\mathrm{EC}, \mathrm{pH}$ and acidity, indicating that blood degree did not influence the physicochemical characteristics of milk 
Table 5. Linear correlation between quality variables and milk production of crossbred Holstein/Gyr cows.

\begin{tabular}{|c|c|c|c|c|c|c|c|c|c|c|}
\hline Parameter & Production & Fat & Protein & Lactose & DDEFFDM & SCC & Urea & EC & $\mathrm{pH}$ & TA \\
\hline GC Breeds & $0.12^{\text {ns }}$ & $0.02^{\text {ns }}$ & $-0.07^{\mathrm{ns}}$ & $0.01^{\mathrm{ns}}$ & $-0.08^{\text {ns }}$ & $0.03^{\text {ns }}$ & $0.08^{\text {ns }}$ & $-0.10^{\text {ns }}$ & $-0.04^{\mathrm{ns}}$ & $-0.05^{\text {ns }}$ \\
\hline Production & - & $0.08^{\text {ns }}$ & $-0.02^{\mathrm{ns}}$ & $-0.22^{* *}$ & $-0.17^{*}$ & $-0.09^{\text {ns }}$ & $0.09^{\mathrm{ns}}$ & $0.03^{\mathrm{ns}}$ & $0.09^{\mathrm{ns}}$ & $-0.07^{\mathrm{ns}}$ \\
\hline Fat & - & - & $0.28^{* *}$ & $-0.14^{*}$ & $0.19^{\star *}$ & $0.08^{\text {ns }}$ & $-0.05^{\mathrm{ns}}$ & $-0.11^{\mathrm{ns}}$ & $-0.01^{\mathrm{ns}}$ & $-0.07^{\text {ns }}$ \\
\hline Protein & - & - & & $-0.17^{\star}$ & $0.75^{\star \star}$ & $0.35^{\star \star}$ & $0.29^{* *}$ & $0.04^{\mathrm{ns}}$ & $0.17^{*}$ & $-0.07^{\mathrm{ns}}$ \\
\hline Lactose & - & - & - & - & $0.48^{* *}$ & $-0.47^{\star *}$ & $0.21^{* *}$ & $-0.54^{\star *}$ & $-0.11^{\mathrm{ns}}$ & $0.36^{* *}$ \\
\hline DDE FFDM & - & - & - & - & - & $0.03^{\mathrm{ns}}$ & $0.39^{* *}$ & $-0.30^{* *}$ & $0.06^{\mathrm{ns}}$ & $0.15^{*}$ \\
\hline SCC & - & - & - & - & - & - & $-0.02^{\text {ns }}$ & $0.32^{* *}$ & $0.13^{\text {ns }}$ & $-0.26^{\star *}$ \\
\hline Urea & - & - & - & - & - & - & - & $-0.14^{*}$ & $-0.03^{\mathrm{ns}}$ & $0.03^{\mathrm{ns}}$ \\
\hline EC & - & - & - & - & - & - & - & - & $0.09^{\mathrm{ns}}$ & $-0.16^{*}$ \\
\hline $\mathrm{pH}$ & & - & 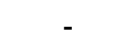 & . & . & - & - & - & - & $-0.12^{\text {ns }}$ \\
\hline
\end{tabular}

${ }^{* *}$ Significant at $1 \%$ probability level $(p<0.01) .{ }^{*}$ Significant at $5 \%$ probability $(p<0.05) . n s=$ not significant $(p \geq 0.05) . T$-test was applied levels of $5 \%$ and $1 \%$. GC = genetic composition; DDE = defatted dry extract; FFDM = fat free dry matter contents; SCC $=$ somatic cells count $(x 1000 \mathrm{SC} / \mathrm{ml}) ; \mathrm{EC}=$ electrical conductivity; TA = titratable acidity.

from primiparous Holstein/Gyr cows. In addition, there was no linear correlation between milk production and fat, protein, SCC, urea, EC, $\mathrm{pH}$ and acidity of milk from primiparous cows.

In Brazil, milk production and fat content are the most productive features for dairy industries in relation to milk payment. The protein content is extremely important, especially for the manufacture of cheese and other dairy products, since protein is determinant of the yield of the final product.

The linear correlation between fat and protein content $(r$ $=0.28$ ) of milk produced by primiparous Holstein/Gyr cows was significant and positive. The higher the fat content of milk produced by crossbred cows, the higher the protein content.

There was a negative correlation at $5 \%$ probability $(p<0.05)$ between fat and lactose $(r=-0.14)$, indicating that the higher the fat content of milk produced by primiparous cows, the lower the lactose content.

The linear correlation between fat content and fat free dry matter DDE $(r=0.19)$ was positive at $1 \%$ probability $(p<0.01)$, showing that the higher the fat content of milk, the higher the fat free dry matter DDE levels, corroborating the results of Oliveira et al. (2010), who evaluated the physicochemical composition of milk at different stages of lactation and found that the fat content, fat free dry matter DDE and lactose were the variables that most varied during the lactation period.

The correlation between fat content and SCC $(r=0.08)$, urea $(r=-0.05)$, electrical conductivity $(r=-0.11), \mathrm{pH}(r=$ $-0.01)$, and titratable acidity $(r=-0.07)$ was not significant $(p>0.05)$.

Different results were reported by Santos, (2005), who observed a negative correlation between EC and fat content, because fat has low capacity to conduct current. According to Rodrigues, (1998), the increased fat content inhibits the EC not only due to the reduction of ions, but also to the physical barrier that fat globules represent for them.

The linear correlation between protein and lactose was negative at $5 \%$ probability $(p<0.05)(r=-0.17)$; these results suggest that the higher the protein content of milk produced by primiparous cows, the lower the lactose content.

The linear correlation between protein content and fat free dry matter DDE $(r=0.75)$, SCC $(r=0.35)$, urea $(r=$ $0.29)$ and $\mathrm{pH}(r=0.17)$ was positive. Under the conditions of this study, increased protein contents has led to a progressive increase in defatted dry extract fat free dry matter, urea, SCC and $\mathrm{pH}$ and milk produced by primiparous cows, corroborating the results obtained in this study. Cunha et al. (2008) observed positive correlation between SCC and protein content of milk from Holstein cows.

Ventura et al. (2006) evaluated the SCC and the effects on milk constituents and found that a minimal increase in the protein content led increase in the SCC values with correlation of 0.2563 .

There was no significant correlation $(p \geq 0.05)$ between protein content, $\mathrm{EC}$ and titratable acidity of milk.

There was a positive correlation $(p<0.01)$ between lactose, fat free dry matter DDE $(r=0.48)$, urea $(r=0.21)$ and titratable acidity $(r=0.36)$ and negative for SCC $(r=-$ $0.47)$, electrical conductivity $(r=-0.54)$ and $\mathrm{pH}(r=-0.11)$, the latter being not significant $(p \geq 0.05)$. This shows that the greater the synthesis of lactose, the greater fat free dry matter content DDE, urea, and TA and the lower the SCC and EC in milk, thus indicating the large number of cows affected with mastitis.

Rajcevic et al. (2003) observed a significant negative correlation between SCC and lactose content $(r=-0.42)$. On average SCC is high, thereby affecting on the correlations, making them significant.

The linear correlation between SCC, fat free dry matter 
DDE and $\mathrm{pH}$ was not significant $(r=0.03)$ and $(r=0.06)$, respectively. The linear correlation of fat free dry matter DDE with urea $(r=0.39)$ was positive and significant at the $1 \%$ level of probability $(p<0.01)$, negative and significant at $1 \%$ with electrical conductivity $(r=0.30)$, positive and significant $(p<0.05)$ with titratable acidity $(r=$ 15).

The correlation between SCC and electrical conductivity $(r=0.32)$ of milk from primiparous Holstein/Gyr cows was positive and significant at $1 \%$ probability $(p<0.01)$. The increase in electrical conductivity of milk is directly proportional to increased inflammation of the udder and SCC. Tavares and Rodrigues, (2010) used the electrical conductivity of milk to assess the health of the udder of dairy cows and found a correlation between EC and SCC of 0.257; and according to the author, the correlation between EC and SCC is in general positive.C

The correlation between SCC, urea and $\mathrm{pH}$ was not significant $(p \geq 0.05)$, but the linear correlation between SCC and titratable acidity was negative but significant at $1 \%$ probability $(p<0.01)$.

There was no correlation $(\mathrm{p} \geq 0.05)$ between urea, $\mathrm{pH}(\mathrm{r}$ $=-0.03)$ and titratable acidity $(r=0.03)$. The correlation between urea and EC $(r=-0.14)$ was negative and significant at $5 \%$ probability $(p<0.05)$, but significantly decreased the electrical conductivity of milk.

There was no significant linear correlation $(p \geq 0.05)$ between $\mathrm{EC}$ and $\mathrm{pH}(r=0.09)$. The correlation between EC and titratable acidity of milk from primiparous cows was negative and significant $(p<0.05)$. This demonstrates that the electrical conductivity does not change the $\mathrm{pH}$ but negatively influence the titratable acidity of milk from Holstein/Gyr cows.

Due to the fact that milk has electrolytes that favor the passage of electric current, the electrical conductivity values of milk can be used to detect abnormal milk, that is, with subclinical mastitis (Zafalon et al., 2005).

Santos (2005) reported that this type of mastitis diagnosis can reach around $80 \%$ sensitivity (correct identification of infected cows) and $75 \%$ specificity (correct identification of healthy cows), that is the use of EC to determine SCC is reliable. However, for greater accuracy, association with SCC results is required.

There was no significant linear correlation between $\mathrm{pH}$ and titratable acidity $(r=-0.12)$. The difficulty of obtaining a good correlation is related to the fact that in determining the acidity, free (ions) and accessible (ionizable/ dissociable) hydrogen protons are measured, on the other hand, only free hydrogen protons (ions) are quantified in $\mathrm{pH}$ determination (Silva, 2004).

Primiparous cows originated from the crossing between Holstein and Gyr stood out for efficient production. Accordingly, it was observed that the milk produced had met the quality requirements set by Brazilian legislation.

Although the values of the chemical components of milk are in accordance with the values required by
Brazilian law, it should be noted that SCC possesses high positive correlation with EC, showing that some animals have subclinical mastitis, with that, the dairy derivatives from milk with high SCC can have their shelf life and their low income, directly influencing the quality of the final product.

\section{Conclusion}

The blood degrees of primiparous Holstein/Gyr cows did not influence the chemical quality of milk. The values of the chemical constituents of milk were considered suitable for human consumption. Titratable acidity and milk production were higher for 3/4 Holstein/Gyr animals.

\section{Conflict of interests}

The authors did not declare any conflict of interest.

\section{REFERENCES}

Almeida R (2007). Raça Holandesa: pontos fortes, limitações de hoje e oportunidades no futuro. Disponível em <http://www.milkpoint.com.br/radar-tecnico/melhoramentogenetico/raca-holandesa-pontos-fortes-limitacoes-de-hoje-eoportunidades-no-futuro36674n.aspx> Acesso em: 25 de nov. de 2013.

Aquino AA, Botaro BG, Ikeda FS, Rodrigues PHM, Martins MF, Santos MV (2007). Effect of increasing dietary urea levels on milk yield and composition of lactating cows. Rev. Bras. Zootec. 36(4): 881-887.

Arashiro EKN, Teodoro VAM, Miguel EM (2006). Mastite bovina: importância econômica e tecnológica. Rev. Inst. Laticínios Cândido Tostes 61(352):32-36.

Botaro BG, Cortinhas CS, Mestieri L, Machado PF, Santos MV (2011). Milk composition and protein fractions from commercial dairy herds. Vet. Zootec. 18(1): 81-91.

Brasil. Ministério da Agricultura, Pecuária e Abastecimento (2011). Aprova o Regulamento Técnico de Produção, Identidade e Qualidade do Leite tipo A, o Regulamento Técnico de Identidade e Qualidade de Leite Cru Refrigerado, o Regulamento Técnico de Identidade e Qualidade de Leite Pasteurizado e o Regulamento Técnico da Coleta de Leite Cru Refrigerado e seu Transporte a Granel. Instrução Normativa no 62, de 29 de dezembro de 2011.

Cerdótes L, Restle J, Alves Filho DC, Nörnberg MFBL, Nörnberg JL, Heck I, Silveira M F (2004). Produção e composição do leite de vacas de quatro grupos genéticos submetidas a dois manejos alimentares no período de lactação. Rev. Bras. Zootec. 33(3): 610622.

Coffey MP, Hickey J, Brotherstone S (2006). Genetic aspects of growth of Holstein- Friesian dairy cows from birth to maturity. J. Dairy Sci. 89(1): 322-329.

Cunha RPL, Molina LR, Carvalho AU, Facury Filho EJ, Ferreira PM, Gentilini MB (2008). Mastite subclínica e relação da contagem de células somáticas com número de lactações, produção e composição química do leite em vacas da raça Holandesa. Arq. Bras. Med. Vet. Zootec. 60(1): 19-24.

Della Libera AMMP, Souza FN, Blagitz MG, Batista CF (2011). Comunicado técnico: Avaliação de indicadores inflamatórios no diagnóstico da mastite bovina. Arq. Inst. Biol. 78(2): 297-300.

Ferreira MA (2007). Dossiê técnico: Controle de qualidade físicoquímico em leite fluído; Centro de Apoio ao Desenvolvimento Tecnológico da Universidade de Brasília - CDT/UnB.

Fukumoto NM, Damasceno JC, Deresz F, Martins CE, Cóser AC, 
Santos GT (2010). Milk yield and composition, feed intake and stocking rate of crossbread cows in tropical grasses managed in a rotational grazing system. Rev. Bras. Zootec. 39(7):1548-1557.

Glória JR, Bergmann JAG, Reis RB, Coelho MS, Silva MA (2006). Efeito da composição genética e de fatores de meio sobre a produção de leite, a duração da lactação e a produção de leite por dia de intervalo de partos de vacas mestiças Holandês-Gir. Arq. Bras. Med. Vet. Zootec. 58(6): 1139-1148.

Hojman D, Gips M, Ezra E (2005). Association between live body weight and milk urea concentration in Holstein cows. J. Dairy Sci. 88(2):580-584.

Huang C, Tsuruta S, Bertrand JK, Misztal I, Lawlor TJ, Clay JS (2009). Trends for conception rate of Holsteins over time in the southeastern United States. J. Dairy Sci. 92(9):4641-4647.

International Dairy Federation (IDF) (2006). 148-2 - Milk - Enumeration of somatic cells - Part 2: Guidance on the operation of fluoro-optoelectronic counters. Brussels, Belgium P. 15.

International Dairy Federation (IDF) 141C (2000). Determination of milk fat, protein and lactose content - Guidance on the operation of midinfrared instruments. Brussels Belgium. 15.

Lima MCG, Sena MJ, Mota RA, Mendes ES, Almeida CC, Silva RPPE (2006). Contagem de células somáticas e análises físico-químicas e microbiológicas do leite cru tipo $C$ produzido na região agreste do estado de Pernambuco. Arq. Inst. Biol. 73(1): 89-95.

Mendes CG, Sakamoto SM, Silva JBA, Jácome CGM, Leite Aí (2010). Análises físico-químicas e Pesqui. de fraude no leite informal comercializado no município de Mossoró, RN. Ciênc. Anim. Bras. 11(2): 349-356.

Mota MF, Vilela D, Santos GT, Elyas ACW, Lopes FCF, Verneque RS, Pinto Neto A (2008). Desempenho produtivo e composição do leite de vacas da raça holandesa no final da lactação, manejadas em pastagem e suplementadas com diferentes níveis de concentrado. Rev. Bras. Ciênc. Vet. 15(2):82-87.

National Research Council (NRC) (1996). Nutrients requeriments of beef cattle. 7.ed. Washington, D.C. 244p.

Noro G, González FHD, Campos R, Dürr JW (2006). Fatores ambientais que afetam a produção e a composição do leite em rebanhos assistidos por cooperativas no Rio Grande do Sul. Rev. Bras. Zootec. 35(3):1129-1135.

Oliveira ENA, Santos DC, Oliveira AS, Sousa FC (2010). Composição físico-química de leites em diferentes fases de lactação. Rev. Acad. Ciênc. Agrár. Ambient. 8(4): 409-415.

Rajcevic M, Potocnik K, Levstek J (2003). Correlations between somatic cells count and milk composition with regard to the season. Agric. Conspec. Sci. 68(3): 221-226.

Rodrigues AM (1998). Condutibilidade eléctrica do leite: um método para detecção de mamites. Escola Superior Agrária do Instituto Politécnico de Castelo Branco, Castelo Branco: 17.

Santos MV (2005). Uso da condutividade elétrica do leite para detecção da mastite. Radares técnicos. Milkpoint. Disponível em: <http://www.milkpoint.com.br/radar-tecnico/qualidade-do-leite/uso-dacondutividade-eletrica-do-leite-para-deteccao-de-mastite26525n.aspx>. Acesso em: 27 set. 2013.

Santos MV, Fonseca LFL (2006). Estratégias para o controle da mastite e melhoria da qualidade do leite. Barueri: Manole: 314 .

Silva DAR, Olivo CJ, Campos BC, Tejkowski TM, Meinerz GR, Sacco AGF, Costa ST (2011). Produção de leite de vacas da raça Holandesa de pequeno, médio e grande porte. Ciênc. Rural 41(3):501-506.
Silva DJ, Queiroz AC (2002). Análise de Alimentos - métodos químicos e biológicos. Viçosa. UFV: 235.

Silva FAS, Azevedo CAV (2009). A new version of the Assistat Statistical Assistance Software. In: WORLD CONGRESS ON COMPUTERS IN AGRICULTURE, Orlando. Proceedings... Reno, RV: American Society of Agricultural and Biological Engineers: 393396.

Silva PHF (2004). Leite UHT Fatores determinantes para sedimentação e gelificação. Ed.01. Juiz de Fora: Templo. 1: 124.

Silva RMO (2012). Estimativas de parâmetros genéticos para habilidade de permanência no rebanho e suas associações com características de interesse econômico em vacas da raça gir leiteiro. Dissertação (Mestrado em Zootec.) - Universidade Federal de Alagoas. Centro de Ciênc.s Agrárias. Rio Largo.

Soares GVM, Rangel AHN, Aguiar EM, Medeiros HR, Lima Júnior DM (2009). Influência da ordem de parto sobre a produção de leite de vacas zebuínas. Acta Vet. Brasilica 3(2): 106-110.

Souza R, Santos GT, Valloto AA, Santos AL, Gasparino E, Silva DC, Santos WBR (2010). Produção e qualidade do leite de vacas da raça holandesa em função da estação do ano e ordem de parto. Rev. Bras. Saúde Prod. An. 11(2):484-495.

Tavares MCV, Rodrigues AMMN (2010). Condutividade eléctrica do leite na avaliação da sanidade do úbere de vacas leiteiras, Universidade dos Açores, Departamento de Ciênc.s Agrárias, Mestrado em Engenharia Zootécnica. Angra do Heroísmo.

Van Melis MH, Eler JP, Oliveira HN, Rosa GJ, Silva JA, Ferraz JB, Pereira E (2007). Study of stayability in Nellore cows using a threshold model. J. Anim. Sci. 85(7): 1780-1786.

Vasconcellos BF, Pádua JT, Muñoz MFC, Tonhati H (2003). Efeitos genéticos e ambientais sobre a produção de leite, o intervalo de partos e a duração da lactação em um rebanho leiteiro com animais mestiços, no Brasil. Revista Universidade Rural: Série Ciênc.s da Vida. 23(1):39-45.

Ventura RV, Leme TARP, Mendonça LC, Dias MS, Amorim MA (2006). Contagem de células somáticas e seus efeitos nos constituintes do leite. II Congresso Brasileiro de Qualidade do Leite. Goiânia Anais: 187-189.

Vilela D, Ferreira AM, Resende JC, Lima JA, Verneque RS (2007). Efeito do concentrado no desempenho produtivo, reprodutivo e econômico de vacas da raça Holandesa em pastagem de coastcross. Arquivo Brasileiro de Medicina Veterinária e Zootec.. 59(2): 443-450.Wang C, Liu JX, Yuan ZP, Wu YM, Zhai SW, Ye HW (2007). Effect of level of metabolizable protein on milk production and nitrogen utilization in lactating dairy cows. J. Dairy Sci. 90(6): 29602965.

Zafalon LF, Nader Filho A, Oliveira JV, Resende FD (2005). Comportamento da condutividade eléctrica e do conteúdo de cloretos do leite como métodos auxiliares de diagnóstico na mamite subclínica bovina. Pesqui. Vet. Bras. 25(3): 159-163. 